The University of Maine

\title{
DigitalCommons@UMaine
}

Sociology School Faculty Scholarship

Sociology

$1-5-2013$

\section{"Putting in your time" : Faculty Experiences in the Process of Promotion to Professor}

Susan K. Gardner

Amy Blackstone

University of Maine - Main, amy.blackstone@umit.maine.edu

Follow this and additional works at: https://digitalcommons.library.umaine.edu/soc_facpub

Part of the Educational Sociology Commons

\section{Repository Citation}

Gardner, Susan K. and Blackstone, Amy, "'Putting in your time" : Faculty Experiences in the Process of Promotion to Professor" (2013). Sociology School Faculty Scholarship. 3.

https://digitalcommons.library.umaine.edu/soc_facpub/3

This Article is brought to you for free and open access by DigitalCommons@UMaine. It has been accepted for inclusion in Sociology School Faculty Scholarship by an authorized administrator of DigitalCommons@UMaine. For more information, please contact um.library.technical.services@maine.edu. 


\title{
"Putting in your time": Faculty Experiences in the Process of Promotion to Professor
}

\author{
Susan K. Gardner • Amy Blackstone
}

(C) Springer Science+Business Media New York 2013

\begin{abstract}
The rank of professor or "full" professor represents the highest status possible for faculty members, and it is generally gained by attaining professional expertise and a national or international reputation. Beyond this, however, little is known about these individuals or the promotion process at this level. In this qualitative study of 10 faculty members at one research university in the United States, we sought to understand the experiences of individuals who had sought promotion to full professor. Through a socialization lens, we found that issues of time, a lack of clarity, and gender disparity were concerns for these faculty members.
\end{abstract}

Keywords Full professor·Promotion · Socialization

Faculty members at the rank of professor or "full professor" have generally attained an advanced level of expertise in their fields (Finnegan \& Hyle, 2009) and a national or international reputation for this expertise as evidenced through scholarship (Long et al. 1993; Miller, 1987). The rank of professor is imbued with increased status, prestige, and influence, not to mention higher salaries (Light et al. 1990; Long et al., 1993; Perna, 2002). As such, the failure to promote a deserving faculty member to the rank of professor may

Susan K. Gardner is Associate Professor of Higher Education at the University of Maine. She received her Ph.D. in Higher Education from Washington State University. Her research interests focus on the intersections of the individual experience within the organizational settings of higher education. She can be reached at susan.k.gardner@maine.edu

Amy Blackstone is Associate Professor and Chair of Sociology at the University of Maine. She received her Ph.D. in Sociology from the University of Minnesota. Her research interests include the experiences of voluntarily childless adults and workers' experiences of and responses to sexual harassment. She can be reached at amy.blackstone@umit.maine.edu

S. K. Gardner $(\bowtie)$

Higher Education, University of Maine, 336 Merrill Hall, Orono, ME 04469-5749, USA

e-mail: susan.k.gardner@maine.edu

A. Blackstone

Department of Sociology, University of Maine, Orono, ME 04469-5749, USA

e-mail: amy.blackstone@umit.maine.edu 
result in a loss of that individual to a different institution (Long et al., 1993) or professional discouragement for that individual, given that mobility between institutions is growing increasingly difficult in many disciplines. Despite having ascended to the highest tier of the professorial ranking system and an arguably influential role in higher education institutions, persons at the rank of professor and the process to gain this rank have been largely neglected in the literature on faculty and the faculty experience.

While focus has been placed on the experiences of those seeking promotion from assistant to associate professor, there has been little attention given to the experiences of faculty who seek promotion to "full." From what literature exists, we know that the promotion process to the rank of professor is fraught with even more ambiguity than what surrounds the tenure and promotion process to the rank of associate professor (Buch et al. 2011; Youn \& Price, 2009). Yet, we know little about the faculty experience of applying for promotion or the individual outcomes of such applications, particularly when they are not initially successful. The purpose of this study was to examine the experiences of 10 faculty members in their quest to attain the rank of professor at one institution. We begin with an overview of the literature relating to the promotion process and then explain the methods utilized in the study. We report the findings of the study; discuss them in relation to the extant literature; and offer implications for policy, practice, and future research.

\section{Literature Review}

Baldwin et al. (2008) alluded to the dearth of research about mid-career faculty, stating that this lack of attention is symptomatic of how many of these faculty members may feel on their campuses. The scholarly literature related to full professors and the promotion experience for those who seek the rank focuses upon (a) the lack of clarity of the process (Buch et al., 2011; Youn \& Price, 2009), (b) the gender imbalances at the rank of professor (Easterly \& Pemberton, 2008; Long et al., 1993; Misra et al. 2010, 2011) and the disproportionate amount of time to attain the rank of professor between men and women (Modern Language Association, 2006). We discuss these themes below.

\section{A Lack of Clarity}

Regarding the tenure and promotion process for assistant professors, Tierney and Bensimon (1996) remarked, "Although the goal is clear - to achieve tenure - the process one should follow to achieve this goal is ambiguous" (p. 39). Moreover, they are not alone in their assessment of the tenure process as ambiguous (e.g., Marshall \& Rothgeb, 2012; Ward \& Wolf-Wendel, 2004; Williams \& Williams, 2006). If a certain level of ambiguity characterizes the tenure process for assistant professors, then it is likely that a lack of clarity also exists for those who seek promotion to full professor.

While it is commonly accepted that the amount of time one spends in rank before seeking promotion to associate professor is traditionally six or seven years (Clark, 1987; Schuster \& Finkelstein, 2006), there is no such general standard when one considers the promotion to full professor. Clark (1987) described this delayed timetable as "perhaps after ten, twelve, or fifteen years" (p. 212). While institutional type influences the promotion to full professor, it is more often merit-based at leading private and public institutions rather than senioritybased as one might find in community colleges and lower ranked public institutions (Clark, 1987). When promotion to full is considered only as a function of time, you "wait your time" (Clark, 1987, p. 215), or you "put in your time" (Finkelstein, 1984, p. 60). When promotion 
is merit-based, however, one typical route is to employ a lengthy evaluation of the faculty member in relation to a national or international reputation (Clark, 1987), which is often evaluated by external review. Either way, the timetable for the application process is rarely, if ever, delineated (Clark, 1987). The concept of time is a significant factor in the promotion to full professor and is highlighted in the sparse literature that exists (Long et al., 1993; Rosenfeld, 1991). Long et al. summarized, "Time in rank and the number of publications in rank are the most important factors determining rates of promotion" (p. 719).

While the triumvirate of teaching, research, and service still reigns supreme in most faculty work-lives (Schuster \& Finkelstein, 2006), the emphasis put on one aspect over another in the quest to attain full professorship varies also by institutional type (Clark, 1987). In one of few studies focusing on such details, Tuckman (1990) examined the probability of gaining the rank of professor in relation to teaching experience, public service, degree level, and experience, finding that the probability of promotion to professor rose in relation to the number of scholarly articles published but to a lesser degree than those seeking promotion to associate professor. Interestingly, Tuckman also found that outstanding teaching had no significant effect on the probability for promotion to full professor and only a small increase of probability in relation to service. He argued, "The academic rewards clearly accrue to those who publish" (p. 127).

In turn, what is often most emphasized for those seeking promotion to full professor at research-oriented institutions is that of a national or international scholarly reputation (Link et al. 2008), which is generally evidenced through publications in prestigious journals or citations of one's work (Fishe, 1998). The extent to which one must be cited or published to attain an international reputation, however, is rarely defined explicitly. Given this ambiguity, the extent to which reviewers agree or disagree about what defines a national or international reputation could be even more fundamental to promotion decisions than one's actual qualifications. Miller (1987) emphasized, "Promotion criteria focus more on the merit of the instructor's professional and scholarly contributions and promise; the criteria for tenure decisions focus more on the long-term worth of the instructor to the institution" (p. 92, emphasis in original).

A corresponding issue that arises in the literature is the "terminal associate professor," or one who either opts out of going forward for promotion to full professor or is so advised (Clark, 1987; Miller, 1987). Unlike the process for the assistant professor when tenure is likely to be an issue, the promotion to full professor can be attempted multiple times at the same institution or never attempted at all. The promotion to full professor is also set apart from that for the assistant professor as it does not usually correspond to a loss of one's position should promotion not occur. To date, no known literature exists that speaks to the experiences of those who have attempted the promotion to professor and were not successful.

\section{Gender Imbalance}

The other area of the existing literature related to the promotion to full professor has identified a gender imbalance present in the rank. Many scholars have commented on this imbalance (Easterly \& Pemberton, 2008; Long et al., 1993; Misra et al., 2010; Misra et al., 2011; Schuster $\&$ Finkelstein, 2006), and the numbers bear out these disparities. Women at the rank of professor in four-year institutions constituted only 26\% of the total in 2009-2010 (U.S. Department of Education, 2010). Buch et al. (2011) explained that women faculty members "stand still at associate" (p. 39). Moreover, when they finally do advance to full professor, it may have taken up to $24.2 \%$ longer than for men (Modern Language Association, 2006). 
The reasons for this disparity are not easily pinpointed. Several scholars have examined the likelihood of men and women faculty members attaining the rank of full professor, controlling for productivity, social capital, and familial status (Long et al., 1993; Perna, 2001, 2005), finding no significant differences between genders. What has been implicated as a possible cause, however, is how men and women faculty members spend their time (Misra et al., 2010). Women at the associate level are more likely to spend more time on teaching and service than on research (Link et al., 2008; Misra et al., 2011) and are likely to give more time to family-related responsibilities (Grant et al. 2000; Ward \& Wolf-Wendel, 2004). It is also well documented that female associate professors are much less satisfied in their academic roles than their male counterparts (Trower, 2011). Buch et al. (2011) found that $10 \%$ of the men in their study reported hesitancy about seeking promotion to full whereas 30\% of the women reported this uncertainty (Buch et al., 2011). While this gender disparity clearly exists, previous studies have typically only focused on national-level data and not the individual-level experience or perspective.

\section{Theoretical Framework: Socialization}

In this study we utilized the lens of socialization in order to understand better the process by which one comes to apply for promotion to full professor. Socialization can be defined as the process through which individuals learn the values, attitudes, norms, knowledge and behaviors to be accepted into a particular organizational culture, in this case, academia (Merton, 1957; Tierney, 1997; Tierney \& Bensimon, 1996; Tierney \& Rhoads, 1994). Tierney and Rhoads stated, "It is the socialization of an individual that makes up the sum total of values and norms that directs a person's daily responses and behavior patterns" (p. xiii). In academia, socialization occurs through both implicit and explicit actions. Implicit socialization more often occurs spontaneously and is difficult to pinpoint whereas explicit socialization is easily observable and organized in cultural structures (Tierney \& Rhoads, 1994). For example, faculty members may be implicitly socialized and learn that attending only certain kinds of meetings is valued whereas they might be explicitly socialized to a particular teaching technique through a faculty development program.

Socialization is often also seen as a two-phase process, initial entry and role continuance (Tierney \& Bensimon, 1996). Initial entry occurs when the individual enters the organization or, in our case, the assistant professor enters the academic institution and begins to "learn the ropes" of the department, discipline, institution, and the profession. While anticipatory socialization will occur during graduate school for many academics, which allows for the student to begin acquiring the values, norms, attitudes, and beliefs of the discipline and the profession, the transmission of the particular attitudes, actions, and values of the institution and department in which they are employed will occur in the early months and years of their faculty appointments (Tierney \& Rhoads, 1994). The second phase, or the one in which associate professors often finds themselves, is the role continuance phase, or the time after which the individual faculty member is situated in the institution. The role continuance phase can be then be considered as the time after probation ends or tenure has been granted.

Socialization in organizational settings can also be described as occurring through different dimensions or strategies, including (a) collective versus individual, (b) formal versus informal, (c) random versus sequential, (d) fixed versus variable, (e) serial versus disjunctive, and (f) investiture versus divestiture (Tierney \& Bensimon, 1996; Van Maanen, 1978), as presented in Table 1. 
Table 1 Socialization strategies

\begin{tabular}{|c|c|c|}
\hline Socialization Strategy & Description of Strategy & Examples in Faculty Role \\
\hline Collective & Group faces a common set of experiences together & New faculty orientation \\
\hline Individual & Individual is socialized alone & \\
\hline Formal & $\begin{array}{l}\text { New recruit separated from existing members of } \\
\text { organization to participate in designated activities }\end{array}$ & New faculty workshop series \\
\hline Informal & Individual learns through trial and error & \\
\hline Random & $\begin{array}{l}\text { Progression of unclear or ambiguous steps leading } \\
\text { to a target goal or role }\end{array}$ & Tenure-promotion process \\
\hline Sequential & $\begin{array}{l}\text { Occurs through identifiable, clear steps to achieve } \\
\text { the goal }\end{array}$ & \\
\hline Fixed & $\begin{array}{l}\text { Precise timetable for moving through } \\
\text { organizational roles }\end{array}$ & $\begin{array}{l}\text { Six years in assistant professor } \\
\text { role }\end{array}$ \\
\hline Variable & Vague and unclear timetables & \\
\hline Serial & $\begin{array}{l}\text { Planned training of individuals by senior } \\
\text { members of the organization }\end{array}$ & Faculty mentoring program \\
\hline Disjunctive & A lack of role models available to guide individual & \\
\hline Investiture & $\begin{array}{l}\text { Affirming and welcoming practices to highlight } \\
\text { diverse experiences of individual }\end{array}$ & \\
\hline Divestiture & $\begin{array}{l}\text { Attempts to strip away the characteristics of the } \\
\text { individual that do not mesh with the } \\
\text { organization's culture }\end{array}$ & $\begin{array}{l}\text { Harassment of newcomers; } \\
\text { paying of dues }\end{array}$ \\
\hline
\end{tabular}

In sum, when comparing the socialization processes of faculty seeking promotion to associate professor with tenure to those seeking promotion to full professor, we see some similarities but, more importantly, several key differences. While both processes have an emphasis on individual strategies and divestiture, the promotion to full process is more ambiguous on each of the remaining socialization dimensions outlined by Tierney and Rhoads (1994) and Van Maanen (1978).

Therefore, when one views the promotion to full professor process through the lens of socialization, it is apparent that at most institutions it is imbued with an individual strategy that is informal and random. Rarely are timetables spelled out, resulting in a variable process; and, while increasing emphasis is being placed on mentoring for those seeking full professor status (Buch et al., 2011), it has traditionally been a disjunctive process. Finally, given the recent studies that have pointed to the dissatisfaction of associate professors across the United States, often due to increased service and teaching expectations after tenure (Jaschik, 2012; Trower, 2011), a divestiture process may also be in play for those who seek to advance to full professor. More specifically, associate professors may be placed in a situation of doing more of what Van Maanen (1978) referred to as the "dirty work" of the organization; and they are thus less able to concentrate on the duties often associated with achieving promotion, like scholarship or research. Tierney and Rhoads (1994) explained:

Individual socialization typically is associated with organizational hierarchies where the organization's participant must learn certain skills, attitudes, and values to handle complex tasks before moving on to a higher status. Passage to a higher status involves winning the approval of organizational gatekeepers who evaluate each participant on an individual basis. (p. 38) 
Finally, it is important to discuss the socialization process as it occurs for underrepresented groups in academia. Tierney and Rhoads (1994) and Tierney and Bensimon (1996) pointed out the differential experience of women and faculty of color in higher education. These individuals are more likely to receive an inadequate anticipatory socialization experience in graduate school, often as a result of weak mentoring relationships, thereby resulting in fewer networking opportunities, divergent priorities, and additional work demands. Faculty members of color and women in underrepresented fields may face additional work demands as a result of cultural taxation or being a tokenized member of one's group, and they may be asked to do additional service or provide mentoring to students from that group (Tierney \& Bensimon, 1996). Consequently, individuals from these groups may face an accumulated disadvantage over time (Clark \& Corcoran, 1986).

The theoretical framework of socialization allows for a deeper understanding of the process to attain promotion to full professor and factors that may influence an unsuccessful attempt. Indeed, this perspective is largely missing in the literature about full professors and their experiences in attempting to attain the rank. While we know that gender imbalance exists at the rank of full professor and that the process is ambiguous, we know little else about this specific rank. Importantly, the voices of those who have experienced the process are missing from the literature.

\section{Method}

Our research question was as follows. "What are the experiences of faculty members at one institution who sought promotion to full professor?" Following Maxwell's (1996) understanding of qualitative research and its purposes, we utilized this approach in order to:

- Understand "the meaning, for participants in the study, of the events, situations, and actions they are involved with and of the accounts that they give of their lives and experiences" (p. 17)

- Understand "the particular context within with the participants act, and the influence that this context has on their actions" (p. 17)

- Identify "unanticipated phenomena and influences

- Understand "the process by which events and actions take place"

As such, we focused our examination in one institutional setting, hereafter referred to as Land Grant University, or LGU. LGU is a mid-sized public institution located in the United States with aspirations to grow its research profile. The faculty ranks at LGU reflect the predominately White institution ( $7 \%$ faculty of color) with an uneven gender balance in the associate and full professor ranks (41\% women and 20\% women, respectively) and an almost equal proportion of women to men at the assistant professor rank ( $48 \%$ women).

The participants were 10 faculty members who had attempted the promotion process to full professor at LGU. The 10 faculty members had responded to an email that was sent to all associate and full professors at LGU in the fall of 2011, which invited response from those who had attempted or had been discouraged from the promotion process to full professor. We were purposeful in including both associate and full ranks as we wanted to understand the experiences of those who had attempted to be promoted but were unsuccessful as well as those who had been successful. As presented in Table 2, the 10 faculty members included six men and four women, including two faculty members of color. The faculty members also represented disciplinary diversity, with six in STEM fields, one in the social sciences, and three in the humanities. 
Table 2 Participant demographics

\begin{tabular}{llllll}
\hline Participant & Gender & Race & Disciplinary Group & First Experience & $\begin{array}{l}\text { Eventually Received } \\
\text { Promotion }\end{array}$ \\
\hline 1 & & & & \\
2 & Man & White & Social Sciences & Discouraged but applied & Yes \\
3 & Man & White & Humanities & Discouraged but applied & Yes \\
4 & Man & Non-White & STEM & Withdrew and reapplied & Yes \\
5 & Woman & White & STEM & Withdrew & Not yet \\
6 & Woman & Non-White & STEM & Withdrew and reapplied & Yes \\
7 & Man & White & Humanities & Rejected and reapplied & Yes \\
8 & Man & White & STEM & Withdrew & No - will not reapply \\
9 & Man & White & Humanities & Rejected and reapplied & Yes \\
10 & Woman & White & STEM & Rejected and reapplied & Yes \\
\hline
\end{tabular}

Of the 10, seven had been promoted at the time we spoke. Three had been rejected the first time they applied but later reapplied and were successful, two had been discouraged from applying but applied anyway, and five had withdrawn their initial applications. Of the five who withdrew, two eventually reapplied and were promoted; two have not yet reapplied but plan to do so, and the final individual has decided never to reapply. The mean number of years of service at LGU was 19.8. The average number of years before these individuals sought promotion was 12.5 from the time of their initial hire, or approximately 6.5 years after being promoted to associate professor.

After obtaining informed consent, we conducted face-to-face interviews with the 10 individuals. Guided by a semi-structured protocol that asked the participants to provide details of their promotion process, the interviews lasted 60 to 120 minutes, were audio-taped, and then transcribed verbatim. We analyzed the transcripts using the constant comparative method (Glaser, 1978) and utilizing NVivo software. In particular, we used Glaser's (1978) steps in data analysis, wherein first we open-coded to understand the larger dynamics at work in the faculty members' perceptions of their disciplinary and paradigmatic differences, resulting in a set of themes. Then, we coded further to make explicit the connections between the themes that emerged and corresponded with the framework of socialization (Tierney \& Rhoads, 1994). Finally, a third round of coding allowed us to search for concepts that tied into the themes (Strauss \& Corbin, 1998) that had emerged from the interviews. We obtained trustworthiness of the data collected and reliability of subsequent analysis through peer debriefing, during which both researchers separately coded and then compared codes and themes to verify analysis.

\section{Findings}

Three main themes emerged from our analysis, and we present the findings below: (a) timing, (b) a lack of clarity, and (c) a gendered experience.

\section{Timing}

As is mentioned in the existing literature, the issue of time loomed largely in the discussions with interviewees. Specific questions reoccurred. When? How long to wait? And when is too soon? 
Six of the 10 participants talked about waiting a particular amount of time before submitting their applications for full professor. This amount of time varied by discipline, and in only two departments was it explicitly outlined. A humanities faculty member explained, "I waited the minimum for the department [name] guidelines, which state that you can come up for full in your third year after receiving tenure." The STEM faculty member commented, "We are required to have 12 years of teaching. So I couldn't have gone up for full before 12 years."

In the other eight departments, however, the timing of the application was not stated; and the faculty members made decisions about when to apply for full based on what they saw others had done. One STEM faculty member commented, "I had gotten tenure in '95, and it was eight years; and I thought I was pretty productive. And that's probably about the normal length of time in our department anyway." Another STEM faculty member explained her experience:

When I was approaching the beginning of my fourth or fifth year I talked to a few people, mostly in my department and my department chair at the time, about going up for full. He said, “I don't see any problems with you going for full, but I would really encourage you to wait until the requisite time interval." I said, "There isn't a requisite time interval for full."

When this faculty member probed further about this "requisite time interval," her department chair explained:

He said, "Well, I just know that there are some people in the department." And I know who he was talking about. It was another woman in our department who is really just a bear, especially with other women in the department. He just said that he anticipated that she would not give me a hard time about going up after the six year interval, but that if I went, in his words, "early," that he could foresee her giving me a hard time. And his reaction was, "Why do that to yourself? Is there a reason you need to hurry and be full?"

These faculty members recognized that one had to put in one's time to be promoted. Indeed, time appeared to be a more important criterion in some departments than the evaluation of applicants' professional accomplishments. One person quipped, "Time is really the key. Is it something that you sort of deserve from being here long enough?"

In turn, the idea of "hurrying" and submitting one's application "too soon" arose in the majority of the faculty members' conversations, particularly since only two departments had explicit expectations about timeline. The fear around submitting too early was one that was based on not wanting to "make waves." A social science faculty member saw a colleague before him wait to apply because "I think he didn't want to make waves. I think he was being a good soldier and waiting his time." He explained, "I think there's a less explicit, or maybe a little less strong, expectation about full that you're expected to wait until you're not going to raise any eyebrows when you go up." Paradoxically, when some waited the time that was either implied or expected, they were told, as was one STEM faculty member, "After I submitted my package and I talked to people outside the department, one person said, 'Oh, no, you should have gone up earlier."”

\section{Lack of Clarity}

Seven of the 10 faculty members repeatedly spoke to the lack of clarity around the expectations for promotion to full professor. All of them, with the exception of the one person in 
the teaching-focused STEM department, talked about the need to have teaching, research, and service evaluated in their applications. However, the extent to which these three areas were valued varied greatly by discipline. For example, a social scientist assumed the evaluation would be weighted heavily toward high quality and impactful publications in top rated journals. He felt he had met this criterion, but his first application was rejected. A STEM faculty member explained the perception of the criteria in his department: "Well, the criteria have nothing specific, but it's really clear that teaching plays very little, if any, role. Service plays very little, if any, role; it just doesn't count." Another STEM faculty member had written a highly cited book but was later told, "Books have absolutely no weight. I was told by my department chair of 12 years not to waste my time writing books." Another STEM faculty member was angry that he was expected to do something that he was never hired to do and said, "I specifically was hired to teach a lot. Then my peer committee gives me shit for not having a steady stream of graduate students. I don't do that kind of work."

When expectations were more clearly spelled out, there were still issues that arose. This lack of clarity led to quite diverse interpretations within departments of their own criteria. A humanities faculty member discussed his department's guidelines, saying,

They're not that explicit. They use words like "normally," but there are no numbers. I think it's something like "substantial amounts of research." It's been discussed at other times that to come up for tenure one needs either a book or a handful of articles. How many fingers you have on that hand is a big question mark. So, it was my understanding that to come up for full one would probably need double that amount, but we don't have [anything explicit]. I think again it says "substantial publications."

Similarly, a social scientist was dumbfounded when his first application to full professor was denied. "The implied expectation in our department is that 10 [publications] will be a minimum to go up for full, and I think at the time I had 13 or 14 in refereed journals," he explained.

What was ultimately problematic when faculty members sought full and were denied, then, was there were no criteria upon which to base these decisions. A social science faculty member shared with us the letter, which informed him that his application had been rejected. He read, "Some members expressed concern that due to his brief time at the associate rank he had not fully met all departmental criteria in the areas of teaching and service," but, he explained, "We don't really have criteria in teaching and service." Often nebulous feedback was provided to those who had been denied the promotion. For example, half of the faculty members mentioned a "reputation for excellence" as a criterion for promotion to full; however, one STEM faculty member was told after being rejected the first time, "I guess the rationale [my department chair] gave was that to be full professor you had to be excellent, and I was average."

However, when asked if clearer criteria would be helpful, only two faculty members agreed. A STEM faculty member said, "Our department has fought pretty hard to be vague but that also leaves some room for unprofessional behaviors." A humanities professor said, "In my department we'd never agree on any language that was more specific." Even more disturbing was a STEM faculty member who, when asked about the helpfulness of specific criteria, rebutted, "No, because I don't think there's any one of our faculty who has ever looked at the criteria. I don't know where it is. I don't think anybody's ever seen it." Another STEM faculty member lamented:

I guess the thing that was the worst for me was that I was taken by surprise; that I thought, since I was exceeding the criteria for post-tenure, that it was a logical next step. There were things I didn't realize I was supposed to be doing. 
Thus, it is perhaps not surprising that, when asked how these experiences impacted their job satisfaction, all participants remarked it that it had influenced their satisfaction on some level. It was common to hear phrases such as "pissed off," "embittered," and downright "anger." A STEM professor explained how he worked to remove this anger: "I remember telling myself that, if I can't get over this, I gotta get out of here because I'm not going to live with that kind of stress in my life and angst and resentment." More often, faculty members talked about how it affected their productivity. A STEM participant described herself as “... less-motivated. I considered just skating through for the rest of my years, not really caring and just doing the bare minimum until I retire."

\section{A Gendered Experience}

While the issue of gender did not come up in every interview we conducted, we were aware of differences based on gender in participants' responses. For example, three of the four women were quick to point out gendered differences in their experiences; and one STEM woman pointed out that there had never been any women promoted to full professor in her area before she applied and was ultimately asked to withdraw her application. She described what she observed, "I saw one woman who had tried three times to get promoted and didn't get it every time. . . . I saw the men getting promoted only." Another STEM woman, who had worked extensively on women's issues within STEM, was also told to withdraw her application before it went through the process. She explained, "It's very common for women in [STEM] who devote time and energy to this [kind of service work] to have this happen." She continued, "But the piece that's directly holding two things in opposition is, if you address difficult issues like this, you will not be meeting the social demands of a male audience." Clearly she felt that the important service work she was doing to increase awareness and retention of women in STEM was ultimately what was keeping her back in her primarily male-dominated STEM department.

Another STEM woman described how the initial refusal of her application was framed within her largely male-dominated field and institution:

I think at one point I was the woman on every damned committee on this campus because I was a woman in the sciences. There were very few of us. So [name], from [other STEM department], and I, we saw each other coming and going. If I wasn't on the committee, she was. And we both did a lot of committee time, clear on up through state committees....But [once my application was rejected], so I pulled myself right out of all of that stuff. I just resigned right and left from everything, except the stuff in my own college and my own department. So, yeah, it affected my job, but maybe for the better. I actually became more focused.

One other STEM woman in a male-dominated department explained how she felt she was perceived whenever she approached the department chair about her concerns in the department:

But when I go to him and I say I have a problem with this, or I want to discuss this, he's just like, "Eh, you worry too much." And it really makes me feel like an idiot, that I'm overly dramatic, that I'm being a hysterical woman, you know. And I said, "I know you don't mean to be dismissive, but you're really making me feel like you're not taking me seriously, and a lot of it has to do with my gender." And he said, "That's ridiculous." 
Yet another STEM woman explained how she had been treated disparately at the time of her first application for promotion and was denied:

It was very interesting because [name], who was at the time in [a social science field], he and I came in the same year. Our records were very similar. We had both been very productive as junior faculty and all of this kind of thing, identical ages, and his went flying through. And he came back to me and he said, "I just can't imagine how they can do that."

Interestingly, a male professor in the humanities discussed how he saw gender playing out in his initial refusal of promotion while he saw a woman with a lesser record being promoted:

And the other thing, of course, is the degree of political correctness. I mean, even as that term is passé, it isn't gone completely. That's what I find interesting: the complaints. Don't get me wrong, I know people. You know, my woman, um, my wife, is in [another humanities] department; we met here. I'm a strong supporter of women getting treated equally, but only equally. I am not in favor of special treatment, unless there are compelling reasons. Certainly, one could make exceptions, I don't dispute that. But the idea that all of the women, or many of the women, in the campus are discriminated against may be true, but in my experience it's just the opposite.

Beyond these examples, it was perhaps even more interesting that it was more often men than women who chose to apply for the promotion even when they had been discouraged from doing so by department chairs and their peers. Women were more apt to listen to this advice and wait, even if later they were told they should not have done so. Men, like one in social science, were more likely to respond thusly, "I really think that if you've put in the work, and you deserve it, then you should do it. And you shouldn't care about whose toes get stepped on." However, women, who had been advised to withdraw - such as a STEM woman - stated, "I left with tears thinking: Forget it, I'll never try."

\section{Discussion}

The experiences of these 10 faculty members at one research institution tell the untold story of those who seek promotion to full professor. From our analysis of the interviews and with the framework of socialization (Tierney \& Bensimon, 1996; Tierney \& Rhoads, 1994), we were able to highlight several issues that arose in these faculty members' experiences that speak to the existing literature.

First, it was apparent that both the individual departments and the overall institution studied had a socialization process for gaining full professor that was at once individual, informal, random, variable, and disjunctive (Van Maanen, 1978). For example, faculty members reported having to rely on observing others to understand when to apply for promotion but were also quite aware of others who had failed before them. Even in the two departments where more fixed and sequential guidelines were provided, the faculty members found themselves failing in their first attempt at promotion. As a disjunctive process, no mentoring existed in any of the departments to assist these individuals in understanding the largely unclear expectations. Similarly, the participants seemed generally unaware of others progressing through the process at the same time as they were. If they had been aware, it might have resulted in a more collectively beneficial experience

Second, it was noteworthy that three of the four women discussed disparate experiences when compared to their male counterparts. Only two of the four women eventually received 
promotion to full professor, and even they discussed disparities in their experiences. While none of the women in our study pinpointed blatant gender discrimination or sexism, there is nonetheless the feeling that "the problem is not one of overt sexism or discrimination but rather that unwelcoming climates are created by unconscious actions that take on gendered meanings" (Tierney \& Bensimon, 1996, p. 81). These women talked about doing work that was not valued because of its gendered focus or being asked to provide more service because of their solo status, particularly in the STEM areas. In the literature, this kind of work has been referred to as "smile work" and "mom work." Smile work, or a culturally imposed strategy that women and faculty members of color use to fit into departments with a tradition of White, male dominance, is often seen as the "symbolic management of behavior to present oneself as being pleasing and agreeable" (Tierney \& Bensimon, 1996, p. 83). Often these behaviors appear non-threatening to a dominant majority in one's department. "Mom work," or "the imposition of nurturing and caretaking roles on women" (Tierney \& Bensimon, 1996, p. 85) is similar to the idea of "smile work" in that the term has been used to describe women being asked or expected to take on more advising of students or even be more nurturing, forgiving, or more disclosing with students when compared to their male peers. Faculty members of color may be asked to advise students of color, advise them in student organizations, or serve on committees so as to represent "diversity" (Tierney \& Bensimon, 1996). Given the fact that persons from these groups are more often engaged in service and teaching demands when compared to their White male counterparts (Kulis et al. 2002; Tierney \& Bensimon, 1996), these characterizations are not far off-mark at LGU.

Regrettably, women and faculty members of color may also feel limited in their aspirations for promotion not only by a lack of role models at a given institution but perhaps also because of what Steele et al. (2002) referred to as stereotype threat as a result of interpreting one's group image negatively. While generally seen in Steele et al.'s work on the performance of African American students and women in mathematics, some of the implications stemming from negative perceptions of one's gender or race, particularly when present in an environment of underrepresentation (i.e., women in a male-dominated STEM department), may also explain some of the issues of hesitancy in pursuing promotion. Certainly, future research could explore these dynamics as well as different constructs upon differing demographic groups.

\section{Implications}

LGU is not anomalous. Indeed, it would not be a stretch to say that LGU represents a typical research institution in regard to its lack of formal policy and structure for promotion to full professor. While most institutions have been persuaded by the voluminous reports and research on the need for more mentoring and guidance for the tenure process (Matusov \& Hampel, 2008), this concept has not yet funneled into current thinking about the promotion process. Instead, LGU mirrors peers in providing no formal mentoring, little structure, no timetable, and few professional development opportunities to assist its associate professors in gaining the rank of full professor. Instead, vague and unclear guidelines often hindered the faculty members' success in the process, resulting in not only repeated applications but also a general feeling of dissatisfaction and disgruntlement, not to mention a lack of motivation to continue one's work. Of course, the purpose of this study was to seek out the experiences of those faculty members who chose to stay at the institution, despite their negative experiences with the promotion process. There may be others who left LGU after a similar experience; but, without a clear system of exit interviewing, LGU's administration and faculty members are left with little opportunity to understand the impact these experiences might have had. 
Institutions like LGU would be well served to consider how to socialize their faculty members so as to prepare them better for promotion to full professor. Instituting a mentoring system and a series of workshops or professional development opportunities would go far in providing a more collective and serial socialization experience. Similarly, department criteria could be considered that might more specifically detail the number of years one might wait until promotion to full professor as well as the explicit expectations to attain the rank. While faculty members may be loathe to develop specific criteria, research has demonstrated that more explicit criteria result in higher levels of faculty satisfaction and success, particularly for women and faculty members of color (Lamont et al. 2004). Without this kind of support, institutions like LGU may end up with more disgruntled, dissatisfied faculty members. When one considers the institutional investment already made in faculty members who have worked their way up through the ranks to seek professorship, faculty dissatisfaction is not a minor concern. Job dissatisfaction is the ultimate predictor of actual turnover (Johnsrud \& Heck, 1994; Smart, 1990). Given today's economic climate and lack of resources to hire new faculty and the resulting lack of mobility of faculty, losing the expertise, leadership, and knowledge of our associate professors is a major concern for everyone.

\section{Limitations and Future Research}

While this study added to the sparse literature about the process of promotion to professor, it was nevertheless not without limitations. The unique context of one institution and the small sample of study participants reduce the generalizability of the findings. Moreover, because of the self-selected sample the findings could represent the perspectives of individuals who may have had overly negative experiences. The inferences drawn from the small, self-selected sample, reflecting gender and disciplinary differences, are, by their nature, limited in scope.

Future studies could continue to explore the process of application to full professor and the experiences of those who engage in it in different contexts and with different constituents. How do those at differing institutional types experience the process? Do expectations differ by institutional type? How do participants from particular disciplines perceive see the promotion process? How do those evaluating the applications view a successful applicant? What are the experiences of those who sought the rank and were immediately successful? How do faculty members from underrepresented groups experience the process? One could also compare and contrast how faculty members from diverse backgrounds have experienced the promotion process. These are simply a few of the many questions that could add to our understanding of this largely under-examined area of academia. Perhaps through a deeper understanding of these faculty members and the process, academia will be able to provide more individuals to lead its departments and institutions in the future.

Acknowledgement The authors would like to acknowledge the support of the National Science Foundation ADVANCE-IT Award \# HRD-1008498.

\section{References}

Baldwin, R. G., DeZure, D., Shaw, A., \& Moretto, K. (2008). Mapping the terrain of mid-career faculty at a research university: Implications for faculty and academic leaders. Change, 40(5), 46-55. 
Buch, K., Huet, Y., Rorrer, A., \& Roberson, L. (2011). Removing the barriers to full professor: A mentoring program for associate professors. Change, 43(6), 38-45.

Clark, B. R. (1987). The academic life: Small worlds, different worlds. Princeton, NJ: Carnegie Foundation.

Clark, S. M., \& Corcoran, M. (1986). Perspectives on the professional socialization of women faculty: A case of accumulative disadvantage? Journal of Higher Education, 57, 20-43.

Easterly, D., \& Pemberton, C. L. (2008). Understanding barriers and supports to proposal writing as perceived by female associate professors: Achieving promotion to professor. Research Management Review, 16(1), 1-17.

Finkelstein, M. J. (1984). The American academic profession: A synthesis of social scientific inquiry since World War II. Columbus, OH: Ohio State University Press.

Finnegan, D. E., \& Hyle, A. E. (2009). Assistant to "full": Rank and the development of expertise. Teachers College Record, 111, 443-479.

Fishe, R. P. H. (1998). What are the research standards for full professor of finance? Journal of Finance, 53, 1053-1079.

Glaser, B. (1978). Theoretical sensitivity: Advances in the methodology of grounded theory. Mill Valley, CA: Sociology Press.

Grant, L., Kennelly, I., \& Ward, K. B. (2000). Revisiting the gender, marriage, and parenthood puzzle in scientific careers. Women's Studies Quarterly, 1-2, 62-85.

Jaschik, S. (2012, June 4). Associate professors less satisfied than those at other ranks, survey finds, Inside Higher Ed. Retrieved from http://www.insidehighered.com/news/2012/06/04/associate-professors-lesssatisfied-those-other-ranks-survey-finds

Johnsrud, L. K., \& Heck, R. H. (1994). A university's faculty: Identifying who will leave and who will stay. Journal for Higher Education Management, 10(1), 71-84.

Kulis, S., Sicotte, D., \& Collins, S. (2002). More than a pipeline problem: Labor supply constraints and gender stratification across academic science disciplines. Research in Higher Education, 43, 657-691.

Lamont, M., Kalev, A., Bowden, S., \& Fosse, E. (2004). Recruiting, promoting, and retaining women academics: Lessons from the literature. Cambridge, MA: Harvard University Press.

Light, D. W., Marsden, L. R., \& Corl, T. C. (1990). A framework for academic careers. In M. J. Finkelstein (Ed.), ASHE reader on faculty and faculty issues in colleges and universities (pp. 98-105). Needham Heights, MA: Ginn Press.

Link, A. N., Swann, C. A., \& Bozeman, B. (2008). A time allocation study of university faculty. Economics of Education Review, 27, 363-374.

Long, J. S., Allison, P. D., \& McGinnis, R. (1993). Rank advancement in academic careers: Sex differences and the effects of productivity. American Sociological Review, 58, 703-722.

Marshall, B. W., \& Rothgeb, J. M. (2012). So you want tenure? Factors affecting tenure decisions in political science departments. Political Science \& Politics, 44, 571-577.

Matusov, E., \& Hampel, R. (2008, January-February). Two approaches to tenure and promotion criteria. Academe, 94(1), 37-39. Retrieved from http://www.aaup.org/AAUP/pubsres/academe/2008/JF/Feat/ matu.htm

Maxwell, J. A. (1996). Qualitative research design: An interactive approach. Thousand Oaks, CA: Sage.

Merton, R. K. (1957). Social theory and social structure. New York, NY: The Free Press.

Miller, R. I. (1987). Evaluating faculty for promotion and tenure. San Francisco, CA: Jossey-Bass.

Misra, J., Lundquist, J., Holmes, E., \& Agiomavritis, S. (2010). Associate professors and gendered barriers to advancement. Amherst, MA: University of Massachusetts.

Misra, J., Lundquist, J. H., Holmes, E., \& Agiomavritis, S. (2011). The ivory ceiling of service work. Academe, 97(1), 22-26. Retrieved from http://www.aaup.org/AAUP/pubsres/academe/2011/JF/Feat/ misr.htm

Modern Language Association. (2006). Standing still: The associate professor survey. Washington, DC: Author.

Perna, L. W. (2001). Sex and race differences in faculty tenure and promotion. Research in Higher Education, $42,541-567$.

Perna, L. W. (2002). Tenure and promotion. In A. M. M. Aleman \& K. A. Renn (Eds.), Women in higher education: An encyclopedia (pp. 440-445). Santa Barbara, CA: ABC-CLIO.

Perna, L. W. (2005). Sex differences in faculty tenure and promotion: The contribution of family ties. Research in Higher Education, 46, 277-307.

Rosenfeld, R. A. (1991). Outcome analysis of academic careers. Durham, NC: University of North Carolina.

Schuster, J. H., \& Finkelstein, M. J. (2006). The American faculty: The restructuring of academic work and careers. Baltimore, MD: The Johns Hopkins University Press.

Smart, J. C. (1990). A causal model of faculty turnover intentions. Research in Higher Education, 31, 405424. 
Steele, C. M., Spencer, S. J., \& Aronson, J. (2002). Contending with group image: The psychology of stereotype and social identity threat. Advances in Experimental Social Psychology, 34, 379-440.

Strauss, A., \& Corbin, J. (1998). Basics of qualitative research: Techniques and procedures for developing grounded theory (2nd ed.). Thousand Oaks, CA: Sage.

Tierney, W. G. (1997). Organizational socialization in higher education. Journal of Higher Education, 68, 116.

Tierney, W. G., \& Bensimon, E. M. (1996). Promotion and tenure: Community and socialization in academe. Albany, NY: State University of New York Press.

Tierney, W. G., \& Rhoads, R. A. (1994). Enhancing promotion, tenure and beyond: Faculty socialization as a cultural process. Washington, DC: George Washington University.

Trower, C. A. (2011). Senior faculty satisfaction: Perceptions of associate and full professors at seven public research universities. Cambridge, MA: TIAA-CREF Institute.

Tuckman, H. P. (1990). The academic reward structure in American higher education. In M. J. Finkelstein (Ed.), ASHE reader on faculty and faculty issues in colleges and universities (pp. 119-137). Needham Heights, MA: Ginn Press.

U.S. Department of Education. (2010). Number of full-time instructional staff at Title IV degree-granting institutions by academic rank, control and level of institution, and gender: United States. Washington DC: Author.

Van Maanen, J. (1978). People processing: Strategies of organizational socialization. Organizational Dynamics, 7, 19-36.

Ward, K. A., \& Wolf-Wendel, L. (2004). Academic motherhood: Managing complex roles in research universities. The Review of Higher Education, 27, 233-257.

Williams, B., \& Williams, S. (2006). Perceptions of African American male junior faculty on promotion and tenure: Implications for community building and social capital. Teachers College Record, 108, 287-315.

Youn, T. I. K., \& Price, T. M. (2009). Learning from the experience of others: The evolution of faculty tenure and promotion rules in comprehensive institutions. Journal of Higher Education, 80, 204-237. 